\title{
Construction as basic translation unit: A case of referring to blind people in English and Ukrainian
}

\author{
Iryna Danylchenko ${ }^{1, *}$ Yana Zhovinsky ${ }^{2}$ \\ ${ }^{1}$ Taras Shevchenko National University of Kyiv, Institute of Philology, Department of Theory and \\ Practice of Translation from English, Kyiv, Taras Shevchenko Blvd., 14, Ukraine \\ ${ }^{2}$ Sutter Medical Center Sacramento, Lactation and Education Department, 2825 Capital Ave, \\ Sacramento, CA 95816, USA
}

\begin{abstract}
The research focuses on the variations in the degrees of equivalence manifested in English and Ukrainian constructions referring to blind people. In this study, patterns consisting of two or more words referring to people with decreasing ability to see, all forms sight impairment are termed blindness-constructions. The results show that in translating from English into Ukrainian blindness-constructions reveal varying degrees of equivalence: from exact correspondence in case of immediate constructions to some sort of constructional mismatch in extended patterns. High degree of equivalence with the immediate blindness-constructions is explained by their fixed form: they include combinations of words with the nouns impairment, sight / vision and the adjective blind describing stable attributes without reference to any specific situation. The modified English blindness-constructions rarely have equivalents readily available in Ukrainian, since their modifying elements broaden or narrow the meaning of immediate constructions restricting their usage to particular contexts in source and target languages. The extended blindness-constructions exhibit a mismatch across the languages. These constructions are made up of two immediate or modified ones and represent the generalized models of situations where translators, forced by the non-existence of identical patterns, have to resort to various strategies.
\end{abstract}

\section{Introduction}

The concept of basic translation unit has been widely discussed in translation studies within a number of approaches treating it variously from separate words and phrases to the whole sentences and text passages. Earlier definitions of a translation unit (Vinay and Darbelnet 1958; Catford 1965; Barkhudarov 1969; Newmark 1988; Shuttleworth and Cowie 1997) focus majorly on the language systems of the source and target languages and how linguistic units of different levels enable establishing equivalence across them. In this vein, Vinay and Darbelnet define a translation unit as "the smallest segment of the

* Corresponding author: danylchenko.iryna@gmail.com 
utterance" [1, p. 21] where the elements "are linked" to make up a single meaningful unit in the source and target languages [ibid.]. Similarly, Barkhudarov treats it as "the minimal unit of the source language (SL) having an equivalent in the target language (TL)" [2]. Two common ideas unite these views - equivalence existing between the elements of different languages and the possibility of establishing it with the units of different linguistic levels. Recent definitions of a translation unit (Kittel et al. 2004; Sorvali 2004; Kondo 2009; Carl and Kay 2011) underline the importance of meaning over form and the priority of function of linguistic elements for a particular audience. According to Sorvali (2004), a basic unit is "a meaningful part of the text on which the translator concentrates at one time" [3, p. 356] which in source and target texts take different shapes.

With a cognitive linguistic turn, translation is seen as the re-creation of the process of meaning construction undergone by the audience of the source text, to activate similar cognitive processes and effects in the recipients of the translated text [4]. From this point of view, basic translation unit is seen as the fragment of speech [5], or rather discourse, having a particular function for a speech community [6, p. 283]. In view of this, the present paper argues that the basic translation unit for establishing equivalence is a construction understood as a pattern consisting of two or more elements (possibly words) integrating form and meaning in a conventionalized way [7]. As constructions include morphemes, lexical items, phrasal and sentence patterns [8], they cover a range of translation issues in an integrated way accounting for various conventions [9] that the speakers of a source and target language use in communication.

This study is a case of referring to blind people in English and Ukrainian. The patterns consisting of two or more words designating people with decreasing ability to see and all forms of sight impairment are termed blindness-constructions. They are divided into immediate, modified and extended $[10,11]$.

Immediate constructions consist normally of two words and designate a situation in a general way out of context, e.g. lose sight, low vision. Modified constructions are enriched with other words [12]. They broaden the meaning of immediate constructions by adding extra info or narrow it indicating specific details. In such a way, a construction's use comes to be restricted to particular contexts, e.g. losing all sight, extremely low vision. In these examples, losing sight is enriched with the quantifier all indicating completeness of sight loss, while low vision is intensified by the adverb extremely. Extended constructions are generalized models of situations depicted in texts [12]. For example, the extended construction low expectations of what blind people can do is generalized as low expectations of what X can do to refer to the situations where blind people need assistance.

This paper aims to demonstrate that the basic translation unit for establishing equivalence is a construction, and I compare news articles in English and Ukrainian about blind people to illustrate how the variations in the degrees of equivalence are manifested in constructions.

News articles are taken as material for analysis, as mass media create an image of disabled people from a particular perspective (medical, social, inclusive etc.) and the choice of constructions in different languages demonstrates the view adopted in these communities. Both English and Ukrainian media claim to have taken a disability-inclusive stance suggesting "authentic and distinctive" representation of people with impairments (bbc.com). So far, verbal representation of disabled people in the media was studied in view of maintaining political correctness suggesting inclusive vocabulary, i.e. words referring to people with impairment, e.g. differently abled, and syntactic patterns such as postmodified nouns, e.g. people with disabilities - люди з обмеженими можливостями, instead of the premodified ones, e.g. disabled people - неповносправні люди. However, verbal representation of people with disabilities in media texts requires analysing words in their 
syntagmatic relations, i.e. constructions, because news discourse represents participants of different events/situations and constructions can show how people are variously described.

The paper is structured in the following way. The outline of previous research suggested in Section 1 will be developed in Section 2, where I will explain the methods I adopt for this investigation. Section 3 will demonstrate varying degrees of equivalence blindnessconstructions reveal in translating from English into Ukrainian. In Section 4 I will discuss the implications of the findings. In the concluding section, I will reflect on further investigations.

\section{Methods}

The study of representation of blind people in English and Ukrainian news texts relies on the ideas of construction grammar [7,8] claiming that language is a repertoire of constructions [12], i. e. more or less complex patterns that integrate form and meaning in a conventionalized way [8]. This implication accounts for the view of translation as a dynamic and fluid activity, since the translator / interpreter constantly evokes various prefabricated units of his source and target languages, e.g. how are you doing? They are entrenched in the memory, non-compositional and convey wider meanings than those of the words forming them [9].

The methodology of the research is based on the analysis of three types of constructions.

The first class - immediate constructions - consist of two words [10] in the source and target languages, e.g. lose sight - втрачати зір, visual impairment - порушення зору. In both English and Ukrainian, they refer to the situations of vision loss in a general way out of context.

By context I mean linguistic and situational background relevant for understanding and rendering the meanings in English and Ukrainian. For one thing, any construction interacts with other words and constructions within the whole text which largely determines their meanings. Therefore, linguistic context is an environment in which a construction appears. For another thing, constructions in the text provide access to the situations in which they function, such as media, technical, medical, sport, legislative etc. The most important feature of the immediate blindness-constructions in English and Ukrainian is that their meaning is the same in all contexts.

The second class - modified constructions - rarely have direct equivalents in English and Ukrainian, since their modifying elements broaden or narrow the meanings of the immediate constructions restricting their usage to particular contexts in source and target languages. To account for the major transformations revealed in the modified constructions in English and Ukrainian, I rely on the conceptual scale generalising over the experience of numbers, quantity, property, etc. [14, p. 23], since modified constructions describe various degrees of vision loss and specific forms of sight impairments relevant to scalar values.

The third class - extended constructions - represents generalized models of referential situations depicted in English and Ukrainian news texts. The extended blindnessconstructions referring to the situations of challenge, support and accessibility exhibit a mismatch across the analysed languages, e.g. English construction challenges for $X$ is rendered variously in Ukrainian texts as перешкоди, труднощі, бар'єри для X.

The language corpus for this study is represented by 60 articles about people with sight impairments published in 2010-2020 on English and Ukrainian versions of BBC news (www.bbc.com) and Ukrainian news sites Hromadske (www.hromadske.ua), UNN (www.unn.com.ua), Zik (www.zik.ua), The Village (www.the-village.com.ua), Obozrevatel (www.news.obozrevatel.com), and Priamyi (www.prm.ua). 


\section{Research results}

The results show that in translating from English into Ukrainian blindness-constructions reveal varying degrees of equivalence: from exact correspondence in case of immediate constructions to some sort of constructional mismatch in extended patterns.

\subsection{The immediate blindness-constructions}

The immediate blindness-constructions represent high degree of equivalence in English and Ukrainian, e.g. lose sight - втрачати зір, visual impairment - порушення зору. Such correspondence is explained by the fixed form of immediate constructions in both languages: they include combinations of two words with the nouns impairment порушення, sight / vision - зір, and the adjective blind - незрячий describing stable attributes without reference to any specific situation.

\subsubsection{Impairment-constructions}

Impairment-constructions are represented by the English word chunk visual impairment and its Ukrainian equivalent порушення зору. In both languages, these constructions have identical morpho-syntactic properties and reveal similar discourse functions: their singular and plural forms fully coincide and they form resembling patterns $X$ have visual impairment / X мас порушення зору and $X$ with visual impairments / $X$ з порушеннями зору.

When used in the singular, the constructions visual impairment and порушення зору designate low vision as a fact, an existing disability people have or not. In the plural, they imply multiple forms of this eye condition.

The common syntactic patterns $X$ have visual impairment and $X$ має порушення зору have a noun $X$ designating a person in the initial position. In both languages, people are introduced first and then follow the verbs have / mae and the constructions visual impairment(s) / порушення зору: I felt like I was the only person having visual impairment (bbc.com 12 Oct. 2019). Спілкуйтесь з людиною, яка має порушення зору так, як ви спілкуєтесь зі знайомими (the-village.com.ua 13 Nov. 2019). This pattern identifies people independently of their disability. As Oliver (1996) argues, any impairment is not an attribute of a person's body; rather it is a social phenomenon, 'a failure of society to accommodate its citizen' [13, p. 42].

The view typical of the English news texts that disabilities can be eliminated by changing the physical and attitudinal structures of society is also found dominant in the Ukrainian news discourse. The patterns $X$ with visual impairments / Х з порушеннями зору locate this disease beside a person, but not inside him, or as Oliver says, 'it (disability) accompanies them but is not part of them [ibid.]. The following English sentence keeps focus on three people: Three people with visual impairments have spoken to the $B B C$ about when they have been targeted for using technology (bbc.com 29 Jan. 2019). A similar Ukrainian example reveals the construction порушення зору in the identical syntactic pattern - the noun люди is followed by the prepositional phrase із порушеннями зору: $У$ бібліотеці встановили спеціальне обладнання, яке допомагає людям із порушеннями зору прочитати потрібну книгу, зайти в Інтернет, написати замітки і не залежати від інших людей (the-village.com.ua 04 Aug. 2018).

\subsubsection{Sight / vision-constructions}


Sight / vision-constructions are based on two patterns - predicative and nominal. The results show that the predicative constructions are equivalent in both languages - the English lose sight / vision regularly corresponds to the Ukrainian втрачати зір. In news texts written in any of these languages this construction implies the process of sight loss or the resultant state across the whole analysed corpus. The following news headlines depict the process of losing vision: Artist losing eyesight 'feels next to useless' (bbc.com 12 Dec. 2020). Відома акторка зізналася, що втрачає зір (unn.com.ua 25 Feb. 2014).

The nominal constructions reveal a slight difference in their meanings: the English word chunks failing sight and deteriorating vision imply a process of sight loss, while their Ukrainian counterparts знижений зір and поганий зір focus on the resultant state. The results show that for the process of sight loss the Ukrainian authors use majorly the predicative constructions with the word sight as the subject - зір падає / погіриується / зникає. In the example below, the construction погіриується зір implies the process of sight loss: Чому погіриується зір у молодому віці та як цього уникнути (hromadske.ua 21 Sep. 2017). In English, the predicative constructions sight fails and sight deteriorated are used rarely. In the analysed text corpus, I have found only two sentences where these constructions are used - in temporal clauses at the end of the sentences to refer to the situations of vision loss which are previously described and are known to the reader.

The construction sight loss and вmpama зору are used identically in English and Ukrainian texts, e.g. Don't feel sorry for my sight loss (bbc.com 06 Sep. 2019). Після втрати зору у мене було 3 роки адаптації, коли я намагався зрозуміти, для чого живу (www.the-village.com.ua 15 Aug. 2017).

\subsubsection{Blind-constructions}

Blind-constructions are similarly represented by the nominal and predicative patterns. The nominal type designates people in English and Ukrainian: the word chunk blind person and незряча людина identify separate individuals; blind pеорle and незрячі люди refer to many persons with the eye conditions and the collective constructions the blind and незрячі describe a mass of them. In both languages, these collocations have the same meanings and discourse functions - they differentiate blind people from those with normal eyesight or partially-limited vision, e.g. 'Disturbing' hallucinations increase during lockdown for blind people (bbc.com 16 Feb. 2021). Я небайдужий до інших незрячих людей (thevillage.com.ua 15 Aug. 2017).

The substantivized adjective the blind reveals an exact correspondence in use with its Ukrainian counterpart незрячі. The next examples similarly describe how blind persons cope with the everyday challenges: As our everyday world moves increasingly online, the digital landscape presents new challenges for ensuring accessibility for the blind (bbc.com 28 Sep. 2019). Як незрячі самостійно орієнтуються в місті і долають перешкоди (the-village.com.ua 15 Aug. 2017). Both English and Ukrainian news reporters prefer the substantivized construction the blind when the word people is already used in the same or previous sentence, e.g. Можливо, проблема в тому, щзо люди бачать мало незрячих на вулииях (the-village.com.ua 15 Aug. 2017).

The predicative construction go blind may be rendered into Ukrainian with the words сліпнути designating the process of sight loss and осліпнути implying the resultant state. Depending on the syntactic pattern, the English construction go blind describes:

a) the beginning of sight loss, e.g. She also fears she will go blind before getting essential treatment (bbc.com 14 Nov. 2019),

b) the development of this condition, e.g. People with serious eye conditions are "sat at home, going blind" because they are afraid to leave their house (bbc.com 23 May 2020). 
The Ukrainian equivalent почати сліпнути conveys the beginning of vision loss: Чоловік оглух $i$ почав сліпнути через татуювання: лікарі знайшли причину (news.obozrevatel.com 29 Aug. 2020), while for the development of this condition there is no construction with the verb сліпнути.

The resultant state is rendered by the English construction gone blind and its Ukrainian equivalent осліпнути: She had gone blind in a matter of days (bbc.com 02 Nov. 2019). Модель з польського міста Врочлава Олександра Садовська вкрила татуюваннями очі, але через невдалу прочедуру осліпла на одне око (news.obozrevatel.com 28 Feb. 2020).

\subsection{The modified blindness-constructions}

The modified English blindness-constructions rarely have equivalents readily available in Ukrainian, since their modifying elements broaden the meaning with extra information or narrow it indicating specific details. In such a way, those elements restrict the constructions' usage to particular contexts in source and target languages.

The results show that major transformations are revealed in the constructions describing varying degrees of vision loss and specific forms of sight impairments. The differences in English and Ukrainian constructions can be explained relying on the conceptual scale generalising over the experience of numbers, quantity, property, etc. [14, p. 23]. As the idea of scalarity permeates the human experience of the quantitative measurement such as having more or less amount of substance, exerting varying degrees of force, or experiencing different intensity of a sensation, the mental scale underlies the meaning of the modified blindness-constructions. Like any scale, it presupposes an implicit norm [15, p. 130], represented in the meanings of the constructions referring to the normally-sighted people. Having a sense of norm is crucial for interpreting the meaning of scalar constructions, since it is only against the norm that varying values on the scale can be identified and assessed [ibid.]. In this vein, such constructions as lost part of central vision, having 20/70 vision etc. are points on the scale marking the degree of deviation from the norm. On the other hand, the existence of such multiple points implies the motion down the scale [16, p. 14] and the constructions like progressive sight loss, the sights is slowly deteriorating etc. measure how a person's ability to see decreases. Accordingly, in our research, two types of modified constructions relevant for establishing equivalence are singled out: those indicating various positions on a scale and those encoding motion along it.

\subsubsection{The positions on the scale}

The varying degree of low vision is marked by the modified constructions of two semantic types - exact and vague. The exact meaning is conveyed by numerical quantifiers and specific category markers. Constructions with the numerical quantifiers include $60 \%$ vision loss, having 20/70 vision in English and мінус 50 відсотків зору and 70 відсотків вже втрачено indicating the proportion of vision impaired. In the analysed English texts, the construction lose sight is rarely specified by the quantifiers, while the phrase have vision can take a numerical modifier, e.g. There are now 16 on the team, with two totally blind and nobody having more than 40\% vision (bbc.com 04 Aug. 2018). Interestingly, numerical quantifiers are common with the construction regain sight as the following example demonstrates: For 15 weeks, I was totally blind but after operations and injections, I regained 20\% of my sight (bbc.com 04 Aug. 2018). On the other hand, the following Ukrainian examples precisely identify the amount of vision lost: Тиждень тому було мінус 50 відсотків иентрального зору. На вчорашній момент - мінус 70 відсотків вже втрачено (zik.ua 25 Jan. 2021). 
English category markers moderatel severel profound/ near-total/ total visual impairment regularly correspond to the Ukrainian constructions знижений зір, слабозорість, залишковий зір аnd повна незрячість indicating particular points on the scale. The following example in Ukrainian demonstrates this gradation: Види порушення зору бувають різні: тотальна незрячість, слабозорість, знижений зір (thevillage.com.ua 13 Nov. 2019).

Vague constructions identify a degree of sight loss in a non-specific and imprecise way. In English the construction lose vision is modified by non-numerical quantifiers the amount and a lot designating large but unspecified quantity, e.g. Three months later the amount of vision I'd lost was quite a lot (bbc.com 18 Sep. 2018). This modified construction has no equivalent in Ukrainian.

Less quantity is implied in English construction losing part of sight modified by the quantifier part of, e.g. A teenager has lost part of his sight after he was punched in the face in an unprovoked attack which caused his glasses to shatter in his eyes (bbc.com 10 Apr. 2004). The latter construction corresponds to the Ukrainian частково втратити зір, e.g. Нардеп Надія Савченко, обвинувачена у державній зраді, заявила, щьо через тиждень сухого голодування частково втратила зір та слух (pravda.com.ua 13 Dec. 2018). On the other hand, Ukrainian vague quantifier частково also modifies the construction повернути зір meaning to regain sight: Їм вдалося частково повернути зір шістьом людям (hromadske.ua 04 Dec. 2020).

\subsubsection{The motion down the scale}

The progression of sight loss is indicated by the constructions marking the initial point on the scale, the motion along it and the ultimate point on it.

The initial point on the scale is designated in English by the modified construction start losing sight, e.g. Imagine you are 28, and you suddenly start losing sight (bbc.com 18 Sep 2018). In this sentence, the construction start losing sight is used with the adverb suddenly emphasizing that the sight loss may begin abruptly and unexpectedly. Similarly this situation is rendered in Ukrainian - the construction nочати втрачати зір is often used with the adverb раптово: За їі словами, чоловік раптово почав втрачати зір через відшарування сітківки та запалення задньої стінки очей (zik.ua 25 Jan. 2021).

Motion along the scale is described variously in English and Ukrainian. In the analysed corpus of English and Ukrainian texts, there are nominal and predicative modified constructions that reveal a mismatch in these languages.

The nominal English constructions progressive sight loss and continual loss of sight are often rendered by the predicative Ukrainian structures nоступово втрачати зір, порушення зору прогресує, зір невпинно падає. In the following example, the English construction progressive sight loss implies movement with no specific time span, manner or speed, e.g. Three years later, he was taken to the Bristol Eye Hospital because of progressive sight loss (bbc.com 03 Sep 2019). In Ukrainian, there is no direct correspondence to this construction, since Ukrainians always specify quick or gradual progression, or otherwise indicate its manner, e.g. хвороба швидко прогресує, зір поступово падає. In the following example, the construction порушення зору може прогресувати is enriched with the adverb шиидко indicating fast and steady progression of sight loss: Небезпека в тому, щз не надто серйозне, на перший погляд, порушення зору може швидко прогресувати та спричинити повну втрату здатності бачити (zik.ua 25 Jan. 2021).

The other nominal construction found in English text corpus - the continual loss of sight - is modified by the adverbial over the years which means limited time continuum, e.g. I found the continual loss of sight over the years very difficult to deal with (bbc.com 08 
Mar 2018). In Ukrainian, such situations are similarly designated by the predicative construction поступово втрачати зір протягом Х років, where the English adjective continual stands for the Ukrainian adverb поступово. The example below captures the 10year time span within which the man was losing his sight: $Я$ nоступово втрачав зір протягом 10 років (the-village.com.ua 15 Aug. 2017). In Ukrainian, slow or rapid sight loss is designated by the constructions with the adverbs поступово and швидко accordingly, e.g. У співака Сергія Бабкіна діагностували рідкісну хворобу: Він шиидко втрачає зір (zik.ua 25 Jan. 2021).

There are three modified constructions to mark the final point on the scale - the English word chunks lose sight completely, have no vision and permanent sight loss corresponding to the Ukrainian повністю втратити зір, нічого не бачити / перестати бачити and зір зник.

In the predicative construction lose sight completely and its Ukrainian counterpart повністю втратити зір the adverbs of degree completely and повністю indicate total blindness, e.g. Gordon Brown has revealed in a new memoir how he feared he might completely lose his evesight during his third year in Downing Street (bbc.com 30 Oct. 2017). Екс-вокалістка Spice Girls повністю втратила зір (prm.ua 20 Мау 2019).

In the constructions have no vision and нічого не бачити the ultimate point of sight loss is marked by the negation nо / не, e.g. Veronica, 22, living in Fairfax, Virginia, has no vision and uses a cane full-time (bbc.com 29 Jan. 2019). Роман розповідає The Village Украйна про те, як жити і пересуватися містом, коли нічого не бачиш (thevillage.com.ua 15 Aug. 2017).

The nominal construction permanent sight loss is rendered into Ukrainian with the predicative structures перестати бачити and зір зник. The following English sentence demonstrates this impairment the ultimate condition that can't further progress, e.g. The assault caused severe lacerations to his cornea which will result in permanent sight loss (bbc.com 10 Apr. 2004). In the Ukrainian sentence, normal vision is represented as disappearing and ceasing to exist by the constructions перестала бачити and зір зник: Спочатку Браун, яка вступає під сценічним ім'ям Mel B, перестала бачити лівим оком, а з часом зір зник й на правому ойі (www.prm.ua 20 Мау 2019).

\subsection{The extended blindness-constructions}

The extended blindness-constructions exhibit a mismatch in English and Ukrainian. Structurally, these constructions include two smaller ones - immediate or modified - and represent the generalized models of referential situations where translators, forced by the non-existence of identical pattern, have to resort to various strategies. This research has revealed two types of situations designated by extended blindness-constructions in English and Ukrainian news texts: internal describing inner states of blind people, their abilities, actions and experiences, and external representing the relations between different participants of events including blind persons, partially-sighted and people with normal vision.

\subsubsection{Internal situations}

Internal situations depict inner states of blind people, their abilities, actions and experiences. Extended constructions of this type refer to the conditions in one eye or both; a person's age, quality of life and adapting to the circumstances. 
For designating blindness in one or both eyes, English and Ukrainian have a different repertoire of constructions. As Table 1 demonstrates, a range of English constructions is not very wide, while Ukrainian word chunks reveal three different patterns.

Table 1. Designating blindness in one or both eyes in English and Ukrainian

\begin{tabular}{|c|c|c|c|}
\hline \multicolumn{2}{|c|}{ English } & \multicolumn{2}{c|}{ Ukrainian } \\
\hline Construction & Extension & Construction & Extension \\
\hline \multirow{2}{*}{$\begin{array}{c}\text { losing sight, having } \\
\text { deteriorating vision, } \\
\text { going blind }\end{array}$} & $\begin{array}{c}\text { in one eye and in the } \\
\text { other, in the right } \\
\text { left eye, in one of } \\
\text { his/ her eyes }\end{array}$ & $\begin{array}{c}\text { став гірше бачити, } \\
\text { перестав бачити }\end{array}$ & $\begin{array}{c}\text { одним оком, лівим / } \\
\text { правим оком }\end{array}$ \\
\cline { 3 - 4 } & $\begin{array}{c}\text { зір зник } \\
\text { осліп одному оці, на } \\
\text { оівому / правому оці }\end{array}$ & $\begin{array}{c}\text { на одне око, на } \\
\text { праве / ліве око }\end{array}$ \\
\hline
\end{tabular}

In English, blindness in one or both eyes is designated by the constructions go blind lose sight and have deteriorating vision extended by the phrases in one eye and in the other, in the right / left eye, or in one of his/ her eyes. The examples below demonstrate that all these extensions share a common pattern with the preposition in:

The then-prime minister, who has been blind in one eye since his teens, told how he tore a retina in the other eye (30 Oct. 2017).

The 24-year-old was in a unit run by Swansea Bay health board when she started losing sight in one of her eyes in June 2018 (01 Oct. 2020).

In Ukrainian, there are three distinct patterns to describe impairments in one or both eyes - one prepositionless and the other two are with the preposition $\mathrm{Ha}$ (corresponding to the English on). First - prepositionless - pattern includes the constructions cmas гірше бачити оr перестав бачити extended by the phrases одним оком ог лівим / правим оком. In this pattern, the extending words are used in the Ukrainian instrumental case without any preposition, e.g. Протягом наступних чотирьох років модель стала гірие бачити лівим оком (news.obozrevatel.com 28 Feb. 2020). This instrumental pattern implies performing an action using eyes as a tool in a particular way.

The other two patterns involve preposition $н а$ which has a distinct locative meaning in Ukrainian. More specifically, it implies the location of object on a surface, such as $\mathrm{Ha}$ столі - on the table. With the construction зір зник come the extensions на одному оиі, на лівому / правому оиі implying location. This Ukrainian construction represents a human eye as a separate entity and the ability to see is conceptually located on its surface. So, sip зник на правому оиі is understood as something which disappeared, vanished or moved away, e.g. Спочатку Браун перестала бачити лівим оком, а з часом зір зник йна правому оuі (www.prm.ua 20 May 2019).

Similarly, an eye with its ability to see is conceptualised in the construction ocлin with the prepositional extensions на одне око, на праве/ ліве око. But unlike the previous example, where vision 'moved away', the construction осліn identifies an entity coming from somewhere and landing on the eye (signaled by the Ukrainian prefix $o$-) and blocking in such a way its ability to see, e.g. Модель з польського міста Вроилава Олександра Садовська через невдалу проиедуру осліпла на одне око (news.obozrevatel.com 28 Feb. 2020). Following Goldberg (2019), I treat complex words like осліп as constructions because they consist of two elements (here the prefix $o$ - and the root cлin roughly corresponding to the English go blind) integrating form and meaning in a conventionalized way [10]. Therefore, I support the general constructionist assumption that constructions 
cover morphemes, lexical items, phrasal and sentence patterns [9], as this claim seems crucial in tackling some complex translation issues.

A person's age is often indicated in the extension to the construction $X$ lost their sight. There are three patterns of the extensions:

(1) indicating an exact age by numerical quantifiers, e.g. She lost sight in her right eye at the age of 11, and in her left eye at 17 (bbc.com 23 sep 2020). У США чотирирічна дівчинка Джейд втратила зір через ускладнення грипу (hromadske.ua 14 Jan. 2020).

(2) measuring a particular period in someone's life, e.g. A woman who lost sight in her teens has been describing the joys of being able to see again after being fitted with a bionic еуе (05 Jan 2016). Людям, незрячим з дитинства, ие потрібно, а мені жодного разу не знадобилося (the-village.com.ua 15 Aug. 2017).

(3) designating a stage of life such as young/ old, e.g. A young woman who lost her sight cannot get funding for a specialist college for the blind (bbc.com 02 Nov. 2019). Загалом втрата зору загрожує більше людям похилого віку (bbc.com 03 Aug. 2017).

Common in both languages is the figurative interpretation of sight as a thing or commodity which people possess. Metaphor SIGHT IS THING underlies the meaning of English construction $X$ with / having visual impairment and its Ukrainian counterpart $X_{3}$ порушеннями зору/ інвалідністю. The following two sentences describe people with visual impairments:

I felt like I was the only person with visual impairment (bbc.com 12 Oct. 2019).

Three people with visual impairments have spoken to the $B B C$ about when they have been targeted for using technology (bbc.com 29 Jan. 2019).

Нешодавно ми з дружиною були на конферениії для людей 3 інвалідністю 6 Kарпатах, де я проводив тренування вестибулярного апарату для незрячих (thevillage.com.ua 15 Aug. 2017).

Не забирайте без попередження білу тростину, за допомогою якої люди 3 порушеннями зору орієнтується у просторі (the-village.com.ua 15 Aug. 2017).

The meanings of constructions (not) get sight back / (не) повернути зір are based on the metaphor SIGHT IS THING. However, the idea of recovery is represented differently in English and Ukrainian. In English, it is depicted as impossible by negation in the construction $X$ won't get sight back where sight is interpreted as an entity inherently valuable and precious [17], e.g. Ian Tibbetts won't get his sight back (bbc.com 02 Nov. 2019). Ukrainian authors avoid negation and prefer the constructions повернути зір and відновити зір extended by the words $я \kappa$ and можна: Багато хто з нас починають замислюватися про те, як повернути зір (bbc.com 16 Nov. 2017). Чи можна відновити зір вправами? (hromadske.ua 24 Jan. 2018).

The extended English construction $X$ 's failing sight led her/ him to V-ing conveys a causative meaning where deteriorating vision forces a person to adapt and change their activity, e.g. She began with four A-levels but her failing sight led to her only managing to complete two (bbc.com 02 Nov. 2019). In Ukrainian causative constructions include the verbs призвести, спричинити, викликати. However, the analyzed Ukrainian corpus reveals that these causative verbs with the construction вmpama зору (sight loss) convey a resultative meaning, е.g. Ця недуга може призвести до повної втрати зору, якщьо ї̈ не лікувати вчасно (news.obozrevatel.com 02 Apr. 2019). Коронавірус може спричинити повну втрату зору (bbc.com 01 Feb 2021). Вони ведуть до повільної втрати зору $i$, окрім того, можуть викликати зорові спотворення реальних об'єктів (zik.ua 23 Oct 2020). On the other hand, deteriorating vision forcing a person to adapt is represented with the verb of compulsion змушувати (make): Bmpama зору змусила Джорджа Редхока шукати нових способів проявити себе (hromadske.ua 30 Nov. 2019).

\subsubsection{External situations}


The extended blindness-constructions referring to external situations are represented in news texts by the word chunks grouped around the ideas of challenge, support and accessibility.

English construction challenges for $X$ is rendered variously in Ukrainian texts as перешкоди, труднощі, бар'єри. The following English sentences refer to the situations where blind people need assistance: But even when digital accessibility is achieved, challenges remain for blind people that are familiar to all (bbc.com 28 Sep. 2019) and As our everyday world moves increasingly online, the digital landscape presents new challenges for ensuring accessibility for the blind (bbc.com 28 Sep. 2019). Ukrainian sentences focus majorly on the barriers - both physical and social: Якщо по дорозі 8 незрячої людини трапляється багато перешкод в незнайомому місиі, вона може просто впасти в ступор і не зрозуміти, як ій це все обійти, чи є прохід вулицею взагалі (www.the-village.com.ua 15 Aug. 2017). Вони не врахували, щяо це заважає незрячим людям. Тростина може оминути перешкоду, а людина спіткнеться об неї

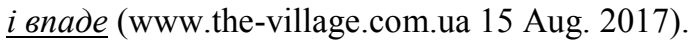

The reason why so few blindness-constructions are used in the external situation contexts is explained by the fact that the relations between blind, partially- and fullysighted participants of events are expressed by the assistance-constructions based on the words support, need, help, provide etc. or obstacle-constructions with the keywords barrier, no way, no access etc., e.g. There is no way forward to resolve the numerous issues (bbc.com 28 Aug. 2019).

The idea of assistance is represented in English by the constructions with the nouns support, assistance and help combining with the verbs have, need, rely on, offer, provide, give, get та accept. In Ukrainian, the assistance-constructions are based on the nouns допомога and підтримка chunking with the verbs отримувати, потребувати, надавати, пропонувати, приймати аnd розраховувати на. In these constructions, the verbs designate static or dynamic aspects of events where blind people interact with other participants.

Relatively stable relations are marked in English by the verbs need and have which imply blind people's need for help and support or its lack on the part of the surrounding people, e.g. "Without certainty over funding for the future the situation is likely to get worse as the number of children who need support continues to increase," she said (bbc.com 02 Oct. 2019). This construction is rendered in Ukrainian as потребувати допомоги, e.g. $\mathrm{Ha}$ сьогоднішній день майже три тисячі важкохворих дітей, якими ми опікуємося, потребують постійної допомоги та підтримки (day.kyiv.ua 17 Apr. 2019). In both examples, the constructions need support and потребують допомоги та підтримки characterize children with impairments who need our care. In the analyzed corpus, English construction need support is modified by the adjectives specialist, professional, academic, the noun government which imply specific kinds of help, and a determiner some conveying vague meaning. In Ukrainian, however, the word chunk потребувати допомоги takes the pre-modifiers професійної, громадської, певної, неабиякої, постійної and post-modifiers лікаря, спеиіаліста, уряду.

English construction have support is usually modified by the definite article and extended by the phrases with the preposition of describing a specific help, e.g., Brandon says having the support of other young people who have faced similar problems, after years of being the "odd one out", has also made a big difference (bbc.com 12 Aug. 2020). In Ukrainian, there is no equivalent to the construction have support.

Dynamic relations between the participants of the events are described by the predicative constructions with the benefactive verbs offer, give, provide and get in English and пропонувати, надавати, забезпечувати and отримати in Ukrainian. In both languages, these verbs differ in their agent-experiencer relation - the verbs offer / 
пропонувати, give / надавати, рrovide /забезпечувати form the constructions focusing on the society as an agent providing support, while get / отримати profile the experiencer, i.e. a blind person who gets assistance.

\section{Discussion}

News texts usually create an image of disabled people from a particular perspective medical, social, inclusive etc. As there is always more than one conventional way for representing any situation verbally, the choice of linguistic means plays a crucial role in news texts. In translating news, encoding a meaning of a source text in the linguistic form of the target language the interpreters have to choose among a wide range of available words and constructions to establish equivalence and render the same referential situation and event perspective. Viewing a language as a repertoire of constructions, i. e. more or less complex patterns that integrate form and meaning in conventionalized way [10], they should be treated as basic translation units. Due to their prefabricated and noncompositional character, constructions not only render various meanings, but in their extended forms are able to capture event perspectives, because their elements participants, actions, objects/ instruments, time, place, results and states - transcend a single event.

This study demonstrates that the more extended the constructions are, the more varying are the ways of rendering them from English into Ukrainian. The immediate blindnessconstructions such as lose sight - втрачати зір, visual impairment - порушення зору represent high degree of equivalence in English and Ukrainian because in both languages they perform the same functions - in news they identify blind people as participants of situations, differentiate them from fully- and partially-sighted persons and describe their stable attributes without reference to any specific situation.

Lack equivalents in English and Ukrainian modified constructions is explained by the fact that they identify particular participants in specific situations; describe their dynamic attributes and changing states.

As major transformations are revealed in the constructions based on the part-whole relations and those indicating various positions on a scale, we can conclude that these semantic relations are variously perceived and understood in these communities.

A striking mismatch is registered among the extended blindness-constructions. Representing the generalized models of situations - internal and external - these constructions vary in English and Ukrainian because they reveal the cognitive background of language use. In separate speech communities, the processes of conceptualisation, categorization and interpretation of reality have their own peculiarities, as it was demonstrated by the English and Ukrainian constructions designating blindness in one or both eyes where English is limited to a small range of constructions and Ukrainian word chunks reveal three distinct locative patterns. Inner states of blind people, their abilities, actions and experiences are various and the relations between different participants of events are complex and multifaceted, and from single lexical instances of spatial expressions like $X$ is below $Y$ versus $Y$ is above $X$ to more elusive discourse-level cases of perspective, like point-of-view narration, the use of constructions captures perspective.

\section{Conclusion}

Under the constructionist approach, the basic translation unit for establishing equivalence is a construction, i.e. a language-specific pairing of form and function with a cluster of properties cutting across the traditional modules of morphology, syntax, 
semantics, and discourse. This research focuses on the variations in the degrees of equivalence manifested in English and Ukrainian constructions referring to blind people.

In this study, patterns consisting of two or more words referring to people with decreasing ability to see, all forms of blindness or sight impairment are termed blindnessconstructions. The results show that in translating from English into Ukrainian blindnessconstructions reveal varying degrees of equivalence: from exact correspondence in case of immediate constructions to some sort of constructional mismatch in extended patterns. High degree of equivalence with the immediate blindness-constructions is explained by their fixed form: they include combinations of words with the nouns impairment, sight / vision, diagnose, condition and the adjective blind describing stable attributes without reference to any specific situation. The modified English blindness-constructions rarely have equivalents readily available in Ukrainian, since their modifying elements broaden the meaning of immediate constructions adding extra information or narrow it indicating specific details and restricting the constructions' usage to particular contexts in source and target languages. The extended blindness-constructions exhibit a mismatch across the languages. Representing the generalized models of situations - internal and external - these constructions vary in English and Ukrainian because they reveal the cognitive background of language use where translators, forced by the non-existence of identical constructions, have to resort to various strategies.

This study is promising because further investigations of assistance- and obstacleconstructions will show from what perspective English and Ukrainian news describe the relations between blind, partially- and fully-sighted participants of events. This study may also be extended to other discourse types, primarily to explore oral communication - public speeches, films etc.

\section{References}

1. J.P. Vinay, J. Darbelnet, Comparative stylistics of French and English: a methodology for translation (John Benjamins, Amsterdam, 1958/1995)

2. L. Barkhudarov, The Translator's Notebooks 6, 3-12 (1969)

3. I. Sorvali, Übersetzung - Translation - Traduction. An International Encyclopedia of Translation Studies 1, 354-362 (Walter de Gruyter, Berlin / NY, 2004)

4. S. L. Halverson, Cognitive Linguistics and Translation: Advances in Some Theoretical Models and Applications, 33-74 (Walter de Gruyter, Berlin / Boston, 2013).

5. M. Thunes, Bergen Language and Linguistics Studies 8 (1), 241-259 (2017)

6. A. Rojo, J. Valenzuela, Cognitive Linguistics and Translation: Advances in Some Theoretical Models and Applications (Walter de Gruyter, Berlin / Boston, 2013)

7. E. Goldberg, Constructions at Work: The Nature of Generalization in Language (Oxford University Press, Oxford, 2006).

8. L.A. Michaelis, Patterns in Language and Linguistics, 193-220 (Mouton de Gruyter, Berlin, 2019)

9. A. E. Goldberg, Explain Me This. Creativity, Competition, and the Partial Productivity of Constructions (Princeton University Press, Princeton, 2019)

10. S.I. Potapenko, Literature and culture of Polissia 89, 172-180 (2017)

11. N. Talavira, Lingua Posnaniensis 59 (2), 101-120 (2017)

12. S. I. Potapenko, K. I. Andriishyna, Cognition, Communication, Discourse 20, 62-72 (2020)

https://drive.google.com/file/d/1HPoQ5rS5cRLHT3ZXE1syXMnSAltLWHYd/view 
13. M. Oliver, Exploring the Divide: illness and disability (Disability Press, Leeds, 1996)

14. M. Johnson, The Body in the Mind : The Bodily Basis of Meaning, Imagination, and Reason (The University of Chicago Press, Chicago / L., 1987)

15. G. Radden, R. Dirven, Cognitive English Grammar (John Benjamin Publ. Comp., Amsterdam, 2007)

16. T. C. Clausner, W. Croft, Cognitive Linguistics, 10 (1), 1-31 (1999) https://doi.org/10.1515/cogl.1999.001

17. I. Danylchenko, Odessa Linguistic Journal 14, 3-12 (2019) http://oljournal.nuoua.od.ua/v14/3.pdf

Word count: 7101 